\title{
King-Denborough syndrome
}

INSERM

\section{Source}

INSERM. (1999). Orphanet: an online rare disease and orphan drug data base. King-

Denborough syndrome. ORPHA:99741

King-Denborough syndrome is a rare genetic non-dystrophic myopathy characterized by the triad of cong enital myopathy, dysmorphic features and susceptibility to malignant hyperthermia. Patients present with a wide phenotypic range, including delayed motor development, muscle weakness and fatigability, ptosis and facies myopathica (with or without creatine kinase elevations), skeletal abnormalities (e.g. short stature, scoliosis, kyphosis, lumbar lordosis and pectus carinatum/excavatum), mild dysmorphic facial features (e.g. hypertelorism, down-slanting palpebral fissures, epicanthic folds, low set ears, micrognathia), webbing of the neck, cryptorchidism, and a susceptibility to malignant hyperthermia and/or rhabdomyolysis due to intensive physical strain, viral infection or statin use. 